\title{
The reform and exploration of teaching mode of automation specialty
}

\author{
Zhang Lanyong \\ College of Automation \\ Harbin Engineering University \\ Harbin China \\ zlyalf@sina.com
}

\author{
Liu Sheng \\ College of Automation \\ Harbin Engineering University \\ Harbin China
}

\begin{abstract}
Based his paper analyzes the main drawbacks of training mode about talents of Control Science and Engineering and points out the major problems of the teaching of automation specialty. And it studies student-centered teaching methods. It can take advantage of teachers who play a role in organization, guidance, facilitate and assistance. It can construct a fun, efficient, participatory and exploratory learning environment to stimulate student's interest in automation specialty courses. By reforming teaching methods, it can improve talents quality of automation specialty and bring up some reliable high-quality talents for our country.
\end{abstract}

Keywords-automation; teaching methods; reform; practice teaching

\section{PREFACE}

The main research of automation specialty is the principles and methods of automatic control, automation cell technology and integration technology and its application in various control systems. It is based on automatic control theory, electronic technology, power electronics technology, sensor technology, computer technology, network and communications technology for the automatic control of industrial processes and industry and automation of various departments $^{[1]}$. It concludes a lot of characteristics as "combination of control and management, combination of strong electricity and weak electricity, combination of software and hardware". It also concludes the characteristics of science, engineering, literature, management. It aims to turn students into senior engineering and technical talents with solid foundation, in-depth technical knowledge of the automatic control system and strong computer application ability. Automation specialty of Harbin Engineering University originated in the "marine electrical automation" and "weapons and equipment automation" of "Harbin Military Engineering Institute", and it officially began enrollment in 1955,the first graduates graduated in 1960, the Ministry of Education specialty catalog made industrial electrical automation, automatic control and production process automation merged into the current automation specialty in $1998^{[2]}$. So far, the current total graduates is more than 3100.After several generations' endeavor, concise professional characteristics, construction of the conditions, automation specialty forms professional advantages characteristics of device system of facing sea and vessel for scientific research and talents training for the country to cultivate a large number of reliable highquality talents.

The National Committee of Defense Industry of Science and Technology organized Beijing University of Aeronautics and Astronautics, Harbin Institute of Technology, Harbin Engineering University and other institutions for full demonstration in 2005 , it suggested that our country should focus on building a number of majors with national defense characteristics to meet the needs of national defense science and technology development and developing defense technology industry high-level talents. Automation specialty of Harbin Engineering University was approved as a national defense characteristic specialty, but there is still a certain contradiction between the professional talents training and the actual demand, it mainly lies in: single training model, engineering absence as well as weak practical aspects, cooperative education is not in place etc. Most of the professional schools recruiting this specialty still follow the traditional training model, which is the pattern of basic courses + Courses + graduation design. After such a training model, students can acquire more solid theoretical basis ${ }^{[3]}$, but they lack the business experience in engineering practice and graduates still need to be trained before reaching their post. In particular, the professional design and experiment and the graduation design are often required to carry out a series of experiments of control systems. However, most colleges don't facilitate such conditions; students can only learn some knowledge of books during the period of school. These graduates can only acquire relevant skills and practical experience after being assigned to companies. It will undoubtedly increase the contradiction between quality of talent cultivation and the actual requirements, and extend the period of talents training. Through the research and exploration of the automation professional teaching methods, the reasonable approach to reform teaching methods for the "Excellence" training mode is proposed to improve the professional quality of talents training of automation specialty.

\section{REFORM OF TEACHING MODE}

It is suggested that we should change the traditional teaching concept what regards teachers, books and classroom as the center. We should establish the teaching concept of students' subject, ability standard and comprehensive quality 
education $^{[4]}$. In the specific teaching, it is suggested that application, practicability vocation of courses are consistent. We should actively introduce foreign advanced teaching mode. Teachers should actively learn from foreign advanced teaching mode in teaching and highlight student-centered teaching philosophy and competency-oriented teaching process.

\section{A. Deepen the teaching research and update the teaching philosophy}

First of all, we can encourage students to study independently and improve students' initiative of participation in the teaching process by acting classroom atmosphere in the interactive and researching teaching model. Secondly, we can deepen students' understanding of the automatic control system and improve lectures effect through multimedia course of video animation and illustrations ${ }^{[5]}$. Then, we can make students understand deeply this concept that learning is used by researching, by combine research project with teaching, theory and practice ${ }^{[6]}$. Meantime, we can get the evaluation of teachers teaching quality by implementation of student evaluation questionnaire and we can get timely the feedback of teaching quality and teaching effectiveness, improving teaching quality. In addition, we should try to produce a large number of achievements with distinct professional characteristics by focusing on improving teaching methods, relying on information technology and improving teaching methods. We should promote the interaction between research and teaching and timely turn scientific research achievements into teaching content, and support undergraduates to participate in research activities, early enter into the issue, laboratory and the team ${ }^{[7]}$.

\section{B. Study advanced teaching methods and teaching methods}

We should make full use of audio-visual equipment, campus network systems, computer multimedia equipment and experimental practice base of advanced equipment to actively promote the teaching methods and means of multimedia teaching, online teaching and field teaching.

\section{Reform teaching methods of specialized courses}

According to the characteristics of automation professional courses, we can reform teaching methods of professional basic courses, main courses and elective courses. Because professional basic courses focus on combining basic theoretical knowledge and practical application closely, teachers should emphasize their application characteristics in the teaching process with the practical application of relevant cases to improve student interest in learning. Main courses strengthen hours proportion experimental curriculum, student-centered research experimental teaching methods, teachers play experimental teaching organization, guidance, facilitate and assist role. We should main strengthen courses' hours proportion of experimental curriculum, research studentcentered experimental teaching methods and make full use of the role that teachers play a role in experimental teaching organization, guidance, facilitation and assistance. We can construct fun, efficient, participatory and exploratory experimental learning environment to stimulate students' interest in automation main courses. Professional elective courses use case-driven approach to improve student learning enthusiasm and enhance students' ability to analyze and solve problems in the design and development of actual case. By reforming the traditional examination and assessment methods and depending on the professional capabilities of the target, we can carry out phased assessment, site assessment, comprehensive evaluation of the ability level of the students to promote the development of students' autonomous learning, inquiry learning and personality.

\section{Focus on the reform of teaching methods, strengthen curriculum development and adhere to combine the three classrooms}

At first, the concept and method of reforming teaching methods is serialization. One is that the "five too much and too little" problem should be proposed in "teaching": too much indoctrination, participatory too little; too many conclusions and too little question; closed-end too much, too little divergent; weighing fraction too much, too little weighing capability; too much book knowledge, practical training is too small. The second is to propose and practice the "five principles" of innovative pedagogy: the question of the main line; integrated guidance; cultivate interest; focus on transformation; encourage a breakthrough. The third is to propose a method and a number of practical teaching reform measures: case teaching; project teaching; experiment and practice teaching; questioning teaching; open teaching content; no standard answers operations; organize discussion sessions; reform examinations; reform interactive theoretical teaching and extracurricular scientific and technological activities and various competitions; reform experimental method and content; reform curriculum design and graduation design. Third is to propose and promote "seven one" of the curriculum construction: a serious and responsible teaching attitude; excellent teaching basic skills; a set of education ideas and teaching methods adapting to social development and requirements of the times; a set of standardized teaching documents; a set of advanced practical textbook; an advanced assessment methods; a set of good experiment. The fourth is to carry out seven measures of second class: expand the number of extracurricular competitions and horizon of students participating in it; carry out qualified engineer certification and professional skills certification; adhere to develop practical ability continuously for four years; introduce the science and technology activities efficiently into the second classroom; promote to open laboratory; actively participate in cultural activities of Students Art Festival; actively participate in various academic activities so that students have more opportunities to participate in various expert reports and lectures. Five is to open up three channels of the third class: cooperate with the institute and enterprise, establish and improve school practice base; students participate in the production, research and research work of teachers so that they can directly enter into production, research and other practical work; social practice of various themes and forms. Sixth is to strengthen the combination of three classrooms: through careful design, the knowledge learned in the first classroom has been consolidated, applied and developed. The second and third classroom promotes the first classroom's reform of teaching content and teaching methods. Three classrooms combine with each other and promote the formation of personnel training environment of the 
whole process multi-link, a large space and system. It meets the demands of students' growth law and demand for talent, and effectively stimulates student interest in learning, improves students' learning ability, practical ability and innovation ability.

\section{PRACTICE TEACHING REFORM}

Orientation of running school based on existing discipline advantages should be made up for the needs of defense and society, and establish a multi-level practice teaching system. By modern motion control, industrial process control, test instrumentation and automation, power electronics technology, electronics and computer technology, information processing technology, we should combine professional features with personnel training requirements to reform practical teaching content, improve the practice of teaching conditions and reform practice teaching pattern so that it can form a complete set of high-quality personnel training programs meeting the requirements of society and defense, and bring up researchbased and Inter-disciplinary talents with the innovative spirit and ability in the field of automation and control. Personnel training process focuses on students' ability of learning, engineering, innovation, entrepreneurship and other integrated capabilities. It reflects the concept of "strong foundation, weigh practice, weighs capacity" so that students not only have a solid foundation of theoretical knowledge, but also have more strong practical ability.

We should make full use of the advantages of "211 Project" key discipline of control theory and control engineering, and pay attention to the important role of research in the process of training talent and building teachers' capacity of research, pay attention to the cultivation of students' basic research quality. All of professional teachers should participated in research work, active commitment to the national and provincial research projects, scientific research and undertake actively the national and provincial research projects. Accumulation of academic cooperation and exchanges with domestic and foreign well-known institutions should be valued, and it is important to create a strong academic atmosphere.

It is suggested that the investment of laboratory construction should be increased and the practice teaching and learning environment should be improved. We should improve the existing basic experimental teaching platform and experiment management platform make more efforts to the construction of laboratory, and encourage and support the professional teachers to develop experimental equipment and educational software based on courses' features.

We should make full use of engineering training center. Engineering training center is capable of teaching and research, practice, production and marketing. It can meet the needs of the professional practice teaching, achieve win-win and improve students' innovative ability. It has a significant effect on optimizing personnel training and improving the quality of teaching. It provides a practical way for our specialty and related specialty to study the integration of industry, academic and research.

It is advised that we should establish Students Innovation Lab and open innovative design practice. In order to strengthen the teaching practice and enhance students' manipulative ability, we should promote the combination of theoretical knowledge, practical skills and innovative qualities, and teaching content should keep up with the development of new theories, new technologies and new processes. To cultivate students' awareness of scientific research innovation, innovation and innovation ability, we should promote the integration of learning in the course of teaching and extracurricular practice so that students can become the subject of teaching activities.

The current application of purchasing creative Labs is very extensive, extremely rapid development of industrial control experimental apparatus and equipment, such as: Embedded (ARM) internship development systems, digital signal processing (DSP) development system, Surplus 61 SCM practice development system, PLC control material sorting device and robot models and engraving machine and circuit board.

We need to improve the function of innovation lab and expand its range of services. Practical teaching of "Automatic Control Theory", "Programmable Controller", "SCM principles and interface technology" courses extend and develop the automatic control professional specialty experiment, and guarantee specialty experimental teaching quality. It lays the foundation for the cultivation of high-quality automatic control personnel. It can also provide technical conditions for the students' Radio Association, the association of electronic technology, and computer society. In addition, because the experimental platform design of the innovative practice room has a flexible modular and extensible features, so it can be used as a training base where students can participate in the challenge cup, electronic design contest and so on.

The creation of innovative educational system, the reform of training program, focusing on the combination of theory and social practice, developing students' practical skills and take the road of combining production and research can achieve the win-win of enterprise, school and student. We can make full use of the long-term relationship with the CSIC 701 Institute,702 Institute,703 Institute,707 Institute,712 Institute of China Aerospace Science and Technology Group, as well as 368 factory signed a joint training agreement in the professional training program. We should adhere to the "employment-oriented, serve as its purpose, the needs of society as the goal, innovative ability as a main line", highlighting the cultivation of innovation ability, adhering to the combination of productivity and teaching and research, emphasizing participation of enterprises, establishing student internships factory in the school, establishing a teaching system that seeing innovation ability and comprehensive quality cultivation as cultivation goal. It highlights the professional characteristics, which has a certain exemplary effort.

It is advised that we should pay attention to practice training, and establish the mechanism of cooperation between industry and University. It can form stable practice base by further strengthen cooperation with Hebei Hanguang Heavy Industry Co., Ltd., Dalian shipbuilding industry group Co., Ltd., Dalian Locomotive factory, Dahua Group, FAW Jiefang Dachai Group and so on. Let enterprise technical personnel enter into the school and carry out teaching in the field of 
engineering education. Let students have a clear reorganization of the professional learning knowledge and its application. Through on-site internship, students can get a better understanding of the knowledge of automation specialty used widely in actual production site. It can enhance students' professional interests and cultivate the ability of students to integrate theory with practice.

\section{PRACTICE TEACHING METHOD REFORM MEASURES}

We should adhere to the "employment-oriented, serve as its purpose, the needs of society as the goal, innovative ability as a main line", highlighting the cultivation of innovation ability, establishing a teaching system that seeing innovation ability and comprehensive quality cultivation as cultivation goal. Through the following measures to carry out the reform of the practice teaching method of "excellence program":

\section{A. Change the experimental teaching idea}

Experiment teaching has an extremely important and special role to train innovative talents, therefore, we must strengthen and improve the experimental teaching, and use experimental methods to improve students' ability and cultivate students' creative desire. In the teaching mode, we need to Break through the traditional concept of "preaching, tuition, doubts", and turn the experimental teaching of single verification of theory and training students' manipulative ability into the cultivation of strengthening students' thinking and creativity ability. On the relationship between theory and experiment, we should find a proper balance, which both attaches importance to the function of the experimental teaching to the theory and the experimental teaching supplement to the theory, the deepening and development; On the relationship between the uniform requirements and personality development, we should give up the traditional teaching mode "preview - to explain - experiment - report," and pay attention to the main role of the students in the teaching activities and the importance of exerting students' ability of initiative and innovation.

\section{B. Optimize the experimental teaching content}

We should breakthrough the traditional proof-test mode, open various types of comprehensive experiment, drastically delete experiments of validation type, replace those basic measurement methods, formulas, validation experiments by demonstration experiments; We should add improving experiment into the professional knowledge of the latest developments of this specialty, and integrate relevant professional theory and skills, especially turn the part what is helpful to train students 'creative ability in science and technology promotion and technology applications into the experimental content to stimulate students' innovation consciousness.

\section{Reform experiment teaching method}

We should abandon traditional stereotyped and programmed teaching methods and closed teaching method teaching methods. We should carry out the implementation of heuristics and open teaching methods to encourage students to learn and design experimental, implementation of process of independent experiment and discussions with each other. Meanwhile, we should reform experiment assessment methods, leaving the experimental examination alone, allowing various forms of test and examination. And we need pay more attention to usual grades, ability, associative thinking and sense of innovation, and make full use of modern educational technology and introduce multimedia teaching methods into experiment teaching.

\section{Comprehensive implementation of open experiment management model}

- Be open in time, namely it takes the implementation of open laboratory management, and allows students to enter into laboratory to do experiments during the normal working hours and night class to provide students with adequate experimental time.

- Open experimental content. We encourage students to use their spare time to enter into the laboratory to do experiments they like or make an electronic small production.

- Strengthen guidance and manage of open-up experimental methods and make full use of the existing equipment, instruments, and improve laboratory utilization. Open training venue, after students completing a curriculum, we need to require students to do some work within a certain period. The ultimate goal of our experiment course, not let the students become "mechanical man", that is in accordance with the instruction books or teachers to pull the switch, write data or write reports. We expect that students' hands and brain can work together through concrete practice, and they can proactively identify and solve problems. It can gradually develop students' ability of independent thinking and manipulative ability.

\section{CONCLUSIONS AND PROSPECTS}

We should take the student as the center, and encourage students' personality development, and promote the common improvement. We should achieve the philosophy of education that students are the center of teaching and teachers are leaders in the process of practice teaching. In teaching settings, assessment, etc., we should adhere to the combination of unity and flexibility, and give full consideration to difference of students on the basic ability, interest, specialty and other aspects, as far as possible to provide personalized development space for students. At the same time, we should find a common feature of the majority of students, and promote development, achieve together improvement. By reforming teaching methods, it can improve talents the quality of automation specialty and train reliable top quality talent for our country.

\section{ACKNOWLEDGMENT}

The work was financed by Control Science and Engineering's Exploration and Practice (2011-16) in Heilongjiang Province, Exploration and Practice in University Teachers' Research and Achievement into Innovative 
Personnel Training's Practice Mechanism (JG2013010202) and Harbin Engineering University undergraduate education reform project Undergraduates' Technology Innovation and Small Business System's Research and Practice (JG2014BYB13), Planning Subject of Education Department of Heilongjiang Province (GBC1213103), Chinese Society of Academic Degree and Graduate Education Research Project(2015Y0403).

\section{REFERENCES}

[1] Li Yongiian,Huang Shaoping,Li Jing. "outstanding engineers" training should pay attention to reforming teaching methods.China University Teaching[J] 2012,11:63-65.

[2] Chen Cixuan,Zhang Yuanfang,Tan Shuntao.Electrical Engineering and Automation Platform Course's Reform Practice and Experience.The second session of the National College of Electrical Engineering and Automation Teaching seminar papers[C]. 2004:538-540.

[3] Zhu Peiyi,Xu Benlian,Xie Qi.The exploration of reforming teaching methods and course system of outstanding engineers education and training programs.China Electric Power Education [J].2012,13:17-18.

[4] Zhang Keju, Li Dongming.The research of reform of teaching method of automation applications talents. Scientific and technological information[J]2008,35:591-592.

[5] Zhang Dejiang,Liu Keping.Teaching reform and team building of automation specialty. Chinese university education [J]2011,9:78-80.

[6] Gao Lixia,Zhang Lijie,Gu Haiping.The reform of teaching pattern of automation course. The exam week[J]2012,62:13-14

[7] Ai Jiaoyan,Wei Shange.Teaching reform and practice of course group of automation professional information.Institute of Higher Education Research[J]2009,28 (3):132-134. 